\title{
Nutritional Quality, Sensory Evaluation, Phytochemicals Analyses and In-Vitro Antioxidant Activity of the Newly Developed Soy Ice Cream
}

\author{
Kanika, M. ${ }^{*}$, Md. Nazim, U. ${ }^{1}$, Nusrat, J. C. ${ }^{2}$, Dipak, K. P. ${ }^{3}$ \\ ${ }^{1}$ scientific officer, Baby food, supplementary food and legume products Section, Institute of food science and \\ technology (IFST), Bangladesh council for scientific and industrial research (BCSIR), Dhaka-1205, Bangladesh. \\ ${ }^{2}$ M. Sc. Student, Applied Nutrition and Food Technology, Islamic University, Kustia, Bangladesh. \\ ${ }^{3}$ Professor, Applied Nutrition and Food Technology, Islamic University, Kustia, Bangladesh \\ "Section in- charge and Senior Scientific officer Baby food, supplementary food and legume products section. \\ Institute of food science and technology (IFST). Bangladesh council of scientific and industrial research (BCSIR) \\ Dhaka-1205, Bangladesh
}

\begin{abstract}
The aim of the study was to develop the soy milk based ice cream and analysis of proximate, minerals, sensory evaluation, phytochemicals and in - vitro antioxidant activity of developed product and compared with traditional market brand ice cream. The compositions of developed ice cream are soy milk $65 \%$, sugar $27 \%$, oil $7 \%$, salt $0.2 \%$ and carboxy methyl cellulose $0.3 \%$. It was found that 100 grams of soy ice cream has $57.1 \pm 1.37 \%$ moisture, $6.98 \pm .04 \%$ fats, $5.47 \pm 0.45 \%$ protein, $29.33 \pm 1.46 \%$ carbohydrate, $0.011 \pm 0.001 \%$ fibre, $0.51 \pm 0.02 \%$ ash and $27.4^{\dagger} 0 \pm 0.61 \%$ sucrose. The protein content is significantly $(\mathrm{p}<0.01)$ higher and fat content is significantly $(\mathrm{p}<0.01)$ lower in soya ice cream than traditional ice cream. Analysis for minerals and heavy metals content was carried out using the Atomic Absorption Spectrophotometer (AAS). $100 \mathrm{gm}$ of soy ice cream contain $25.59 \pm 0.43$ $\mathrm{mg}$ calcium, $5.46 \pm 0.96 \mathrm{mg}$ iron, $11.16 \pm 0.48 \mathrm{mg}$ magnesium, $0.80 \pm 0.07 \mathrm{mg}$ zinc, $17.35 \pm 0.70 \mathrm{mg}$ potassium, $86.43 \pm 0.71 \mathrm{mg}$ sodium $0.24 \pm 0.01 \mathrm{mg}$ manganese, and $0.56 \pm 0.03 \mathrm{mg}$ copper. Heavy metals were not present in developed product. Sensory attributes of this product is very much acceptable. Phytochemicals and in- vitro antioxidant models studied were the total antioxidant capacity by phosphomolybdenum method, FRAP assay , 2, 2-diphenyl-1-picrylhydrazyl (DPPH) free radical scavenging activity and reducing power done by spectrophotometrically. The contents of phenolics, flavonoids and tannin are $23.69 \pm 0.45 \mathrm{mg}$ tannic acid equivalent, $14.57 \pm 0.45 \mathrm{mg}$ catechin equivalent and $3.81 \pm 027 \mathrm{mg}$ catechin equivalent in $100 \mathrm{gm}$ sample respectively. Flavonoids and tannin were not present in traditional ice cream. The total antioxidant capacity is $505.60 \pm 9.77 \mathrm{mg}$ ascorbic acid equivalent in phosphomolybdenum method and $62.13 \pm 1.05 \mu \mathrm{mol}$ ascorbic acid/100 gm fresh soy ice cream in FRAP assay and $\mathrm{IC}_{50}$ of soy ice cream in DPPH assay is $156.24 \mathrm{mg} / \mathrm{ml}$ whereas IC 50 of standard ascorbic acid in DPPH assay is $5.69 \mu \mathrm{g} / \mathrm{ml}$ but traditional ice cream has no DPPH free radical scavenging activity. The IC ${ }_{50}$ in reducing power assay of soya ice cream, traditional ice - cream and standard ascorbic acid were $197.51 \pm 0.83 \mathrm{mg}, 228.98 \pm 1.74 \mathrm{mg}$ (fresh weight) and $31.12 \pm 0.13 \mathrm{mg}$ respectively. Total anti oxidant activity and phytochemicals are significantly ( $p<0.001$ and $p<0.01$ ) higher in soya ice cream than the traditional ice cream. The experiments repeated three times in all cases. The findings are soya ice cream is better than traditional ice cream.
\end{abstract}

Keywords: Soy ice cream, Proximate, Minerals, Antioxidant, Phytochemicals and $\mathrm{IC}_{50}$.

\section{INTRODUCTION}

Ice-cream is a frozen mixture of milk components, sweeteners, stabilisers, flavourings and other ingredients. Ice cream ingredients, especially milk fat and milk solid, are used for product classification in accordance with legislation (Wiwat, 2012). There are many kind of ice cream are present in the world. But vegetarians and health enthusiasts have known for years that foods rich in soy protein offer a good alternative to meat, poultry, and other animal-based products. As consumers have pursued healthier lifestyles in recent years, consumption of soy foods has risen steadily, encouraged by scientific studies showing health benefits from these products. There are many soy-based frozen desserts in the market, but there is no evidence of a commercial frozen dessert formulated with

\footnotetext{
*Corresponding Author: mitra.kanika@gmail.com
} 
soy. Because the non-dairy frozen desserts lack the milk-fat, which makes the product creamier that are often related with soy-based frozen desserts.

Soybeans are the most important food source of isoflavones, which have been associated with beneficial health effects in humans, including prevention of cancer, cardiovascular diseases, osteoporosis, and relief of menopausal symptoms (Messina and Lane, 2007). There are 12 isoflavones in soybeans and soy products, 3 free aglycones (genistein, daidzein, and glycitein) and their respective glucosidic, malonyl, and acetylglucosidic conjugates (Murphy et al.,). In addition, soya milk is a liquid extract of soya bean, a good dietary source containing almost all components of soya bean which are beneficial to health, such as peptide and protein, lectin, trypsin inhibitor, dietary fibre, oligosaccharide, phytin, saponin, isoflavone, linoleic acid, linolenic acid, lecithin, tocopherol, plant sterol, vitamin $\mathrm{K}$ and minerals (Wiwat, 2012).

Plants consumed by humans may contain many different phenolic compounds and soya is special one from these plants. Dietary phenolics have antioxidative and possible anticarcinogenic activities. A popular belief is that dietary phenolics are anticarcinogens because they are antioxidants, but direct evidence supporting this supposition is lacking (Yang, 2001). Phenolics may inhibit carcinogenesis by affecting the molecular events in the initiation, promotion, and progression stages. The bioavailability of the dietary phenolics has been discussed extensively, because the tissue levels of the effective compounds determine the biological activity. Epidemiological studies concerning consumption of phenolics and human cancer risk suggest the protective effects of certain food items and phenolics, but more studies are needed to reach clear-cut conclusions (Takahashi, 2005). Several approaches have been undertaken to include more soya bean in the diet for better health of the people and new soya recipes have been developed.

The aim of the study was to develop new soya ice cream and determination of proximate, minerals, sensory evaluation, phytochemicals and in-vitro antioxidant activity of soy-ice cream and compare with traditional ice cream available in Bangladesh.

\section{MATERials AND METHODS}

\subsection{Chemicals}

Chemicals are collected from Merck Germany, sigma Aldrich, BDH UK, Merck India, etc. and all chemicals are analytical grade.

\subsection{Samples}

Traditional ice cream was collected from local market (Sapno super store, Dhanmondi, Dhaka-1205) in capital city Dhaka. Soya was collected and cleaned. Soya milk was developed after dehulling the soya and trypsin inhibitor destroyed by heating. The ingredients of soya ice cream are Soya milk 65.0\%, Sugar $25.0 \%$, Oil 5.0\%, Salt 0.2\% and $\mathrm{CMC} 0.3 \%$. Color and flavor are added in adequate amount. The mixture was pasteurized, homogenized and held overnight in a refrigerator before freezing, together with vigorous agitation until it formed a semi-solid consistency. The ice cream was then packaged and placed into a freezer for hardening and storing (Wiwat, 2008).

\subsection{Extraction of the Sample}

A total of near about $0.5-1.0 \mathrm{~g}$ of soy ice cream was extracted by vortex, mechanical shaking for four hours and finally sonication for 20 minutes with $50 \mathrm{ml}$ methanol. Methanol extract was obtained by filtering the mixture through Whatman No. 1 filter paper and the supernatant was used in the experiment. The extraction repeated three times.

\subsection{Proximate and Other Chemical Analysis}

\section{Determination of Moisture Content}

The method described by Pearson (1999) was used. Moisture content was determined as the loss in weight due to evaporation from sample at a temperature of $105^{\circ} \mathrm{C}$.

\section{Determination of Ash}

This was determined according to the method described by Pearson (1999). The crucible with sample was gently heated on the Bunsen flame until smoke ceased, and then transferred into a muffle furnace where it was burnt at $600^{\circ} \mathrm{C}$ to white ashes. The crucible and its contents were then removed and placed in a desiccator to cool after which it was weighed to a constant weight and calculated the amount of ash content. 


\section{Determination of Crude Protein by Kjeldahl Method}

The method described by Pearson (1999) was used. The nitrogen content was multiplied by 6.25 (conversion factor) to obtain the percentage protein for soya ice-cream and 6.38 for traditional ice-cream respectively. The procedure was carried out in three stages: digestion, distillation and titration.

\section{Determination of Fat}

Determination of fat was carried out by Werner-Schmid process (Pearson, 1999). Proteins are digested with conc. hydrochloric acid. Liberated fat is extracted with alcohol, ethyl ether and petroleum ether. Ethers are evaporated and residue left behind is weighed to calculate the fat content.

\section{Determination of Crude Fibre Content}

The crude fibre content was carried out using the method described by Pearson (1999). 2-4 g of sample was defatted. The defatted sample was boiled under reflux for 30 min with $200 \mathrm{ml}(1.25 \%) \mathrm{H} 2 \mathrm{SO}$. It was further filtered and washed with boiling water until the washing was no longer acidic. The residue was boiled in a round bottom flask with $200 \mathrm{ml}(1.25 \%) \mathrm{NaOH}$ for another 30 min filtered and washed with boiling water until the washing was no longer alkaline. The residue was scraped into a previously weighed crucible and dried at $100^{\circ} \mathrm{C}$. It was left in a desiccators to cool and weighed. It was thereafter incinerated in a muffle furnace at about $600^{\circ} \mathrm{C}$, left in a desiccator to cool and then weighed and calculated the crude fibre.

\subsection{Carbohydrate Estimation}

Carbohydrate content was calculated by subtraction of the sum of moisture, protein, fat, crude fibre and ash contents.

\subsection{Total Energy (Calorific Value) Determination}

The energy value was calculated using the Atwater factor method $[(9 \mathrm{x}$ fat $)+(4 \mathrm{x}$ carbohydrate $)+(4 \mathrm{x}$ protein $)]$ as described by Eneche (1991); Chinma and Igyor (2007) and Nwabueze (2007). The proportion of protein, fat and carbohydrate were multiplied by their physiological fuel values of 4,9 and $4 \mathrm{kcal}$, respectively and the sum of the product was taken.

\subsection{Determination of Sucrose}

Sucrose was determined by the copper reduction method (Pearson, 1999).Extraction of sugar was carried out by 50 $\%$ alcohol and clearing agents were lead acetate and di -potassium oxalate. Inversion of the sugar was done by using hydrochloric acid and then mild heating in water bath. Finally dilute to mark, filter and determine the sucrose by Lane and Eynone's method using standard Fehling solution. Sucrose \% was determined by following formula.

Sucrose $\%=($ TI-BI $)$ X 0.95

Where $\mathrm{BI}$ is \% of reducing sugars before inversion and TI is \% of reducing sugars after inversion.

\subsection{Determination of Lactose}

Lactose was determined by the copper reduction method (Pearson, 1999). Weight the sample into 250ml volumetric flask, dilute with hot water and allow standing for 30 minute. Cool and add $4 \mathrm{ml}$ carrez I solution, mix and $4 \mathrm{ml}$ carrez II solution. Finally dilute to mark, filter and determine the lactose by Lane and Eynone's method using standard Fehling solution.

\subsection{Total Solid Content}

Total solid content of the both ice cream were determined gravimetrically by drying a sample to constant weight in an oven at $105^{\circ} \mathrm{C}$. Ice cream samples were crushed with $20 \mathrm{~g}$ sea sand and glass stick in pre dried weighing dish. The difference in weight before and after drying for $4-5$ hours at $105^{\circ} \mathrm{C}$ gives the results of total solid content (Method 33.2.44; 990.20, AOAC 2006).

Total solid content $(\%)=[($ Total solid content of ice cream $(\mathrm{g}) /$ ice cream $(\mathrm{g}))] \times 100$

\subsection{Minerals and Heavy Metal Determination}

Minerals were determining according to Pearson's, 1999 .Weight the sample and ash was prepared in muffle furnace. The stock solution was prepared by using hydrochloric acid and then minerals and heavy metals were determined by using the Atomic Absorption Spectrophotometer (AAS), model: Thermo scientific, ICE 3000 series. 


\subsection{Sensory Evaluation}

The sensory evaluation of the 'soya ice cream' was conducted at the director meeting room in presence of our honorable director, IFST. The experiment conducted by quality control section chief, IFST according to Isong $\mathrm{et} \mathrm{al}$., 2013. Scientists from the institute of food science and technology (IFST) were randomly selected to evaluate the likeness of soya ice cream. The nine hedonic scale where nine was the highest and one the lowest scores was employed. The rating scale for the degree of likeness were as follows: 9 - like extremely; 8 - like very much, 7 - like moderately; 6 - like slightly, 5 - neither like nor dislike, 4 - dislike slightly, 3 - dislike moderately; 2 - dislike very much, and 1 - dislike extremely. 'Soya ice cream' was presented to the judges in white plastic plates.

Tap water was provided for the judges to rinse their mouth in between evaluation. The judges evaluated "soya ice cream' for appearance color, texture, flavor, softness, taste and overall acceptance.

\subsection{Phytochemicals and In-Vitro Antioxidant Activity Analysis}

\section{Total Phenolic Content (TPC)}

The amount of total phenol content can be determined by Folin-Ciocateu reagent method (McDonald et al., 2001). $0.5 \mathrm{ml}$ of extract and $0.1 \mathrm{ml}$ of Folin-Ciocalteu reagent $(0.5 \mathrm{~N})$ are mixed and incubated at room temperature for 15 min. Then $2.5 \mathrm{ml}$ saturated sodium carbonate was added and further incubated for $30 \mathrm{~min}$ at room temperature and absorbance measured at $760 \mathrm{~nm}$ spectrophotometrically (Specord 205, double beam). Tannic acid (Wolfe et al., 2003 was used as positive controls. The total phenolic content is expressed in terms of standard equivalent (mgg-1 of extracted compound).

\subsection{Total Flavanoid Determination}

Total flavonoid content was determined by Aluminium chloride method (Chang et al., 2002) using catechin as a standard. $1 \mathrm{ml}$ of test sample and $4 \mathrm{ml}$ of water were added to a volumetric flask (10 ml volume). $5 \mathrm{~min}$ after adding $0.3 \mathrm{ml}$ of $5 \%$ Sodium nitrite, $0.3 \mathrm{ml}$ of $10 \%$ Aluminium chloride was added. After 6 min incubation at room temperature, $2 \mathrm{ml}$ of $1 \mathrm{M}$ Sodium hydroxide was added to the reaction mixture. Immediately the final volume was made up to $10 \mathrm{ml}$ with distilled water. The absorbance of the reaction mixture was measured at $510 \mathrm{~nm}$ against a blank spectrophotometrically (Specord 205, double beam).Total flavonoid content was calculated as catechin $(\mathrm{mg} / 100 \mathrm{~g})$ using the following equation based on the calibration curve: $\mathrm{y}=574.4 \mathrm{x}-2.171, \mathrm{R} 2=0.992$, where $\mathrm{x}$ was the absorbance and y was the catechin concentration.

\subsection{Tannin Content Determination}

Quantitative estimation of tannin was carried out using the modified vanillin- $\mathrm{HCl}$ method (Abdelseed et al., 2011). Vanillin reagent $(0.5 \%, 5 \mathrm{ml})$ was added to the extract $(1 \mathrm{ml})$ and the absorbance of the color developed after 20 minutes at $30^{\circ} \mathrm{C}$ was read at $500 \mathrm{~nm}$. A standard curve was prepared expressing the results as catechin equivalents, i.e. amount of catechin (mg $100 \mathrm{~g}-1$ ) which gives a colour intensity equivalent to that given by tannin after correcting for blank. Tannin content was calculated as catechin $(\mathrm{mg} / 100 \mathrm{~g})$ using the following equation based on the calibration curve: $\mathrm{y}=1298 \mathrm{x}+2.954, \mathrm{R} 2=0.996$, where $\mathrm{x}$ was the absorbance and $\mathrm{y}$ was the catechin concentration.

\subsection{Determination of Total Antioxidant Capacity}

The determination of total antioxidant activity was done as per the phosphomolybdenum method with some modifications (Alakh et al., 2011). The basic principle of the assay is based on the reduction of Mo (VI) to Mo (V) by the extract and subsequent formation of a green phosphate Mo $(\mathrm{V})$ complex at acidic $\mathrm{pH}$. $0.3 \mathrm{ml}$ extract was combined with a mixture of $3 \mathrm{ml}$ of reagent solution $(0.6 \mathrm{M}$ sulfuric acid, $28 \mathrm{mM}$ sodium phosphate and $4 \mathrm{mM}$ ammonium molybdate). The tubes containing the reaction solution were then capped and incubated at $95{ }^{\circ} \mathrm{C}$ for 90 minutes. After the samples had cooled to room temperature, the absorbance of the solution was then measured at $695 \mathrm{~nm}$ against blank. Methanol $(0.3 \mathrm{ml})$ in the place of extract is used as the blank. The antioxidant activity is expressed as the $\mathrm{mg}$ of equivalents of ascorbic acid.

\subsection{Determination of Ferric Reducing Antioxidant Power Assay (FRAP)}

FRAP assay was carried out according to the method of Maizura et al. (2011) with some modification. FRAP reagent was prepared from acetate buffer (1.6 g sodium acetate and $8 \mathrm{ml}$ acetic acid make up to $500 \mathrm{ml}$ ) (pH 3.6), 10 $\mathrm{mM}$ TPTZ solution in $40 \mathrm{mM}$ HCL and $20 \mathrm{mM}$ iron (III) chloride solution in proportion of 10:1:1 (v/v) respectively. The FRAP reagent was prepared fresh daily and was warmed to $37 \mathrm{oC}$ in oven prior to use. A total of $200 \mu \mathrm{l}$ samples extract were added to $4 \mathrm{ml}$ of the FRAP reagent and mixed well. The absorbance was measured at $593 \mathrm{~nm}$ using 
using UV-visible spectrophotometer (Specord 205, double beam). Samples were measured in three replicates. Standard curve of ascorbic acid ( $125 \mu \mathrm{mol}, 250 \mu \mathrm{mol}, 500 \mu \mathrm{mol}, 750 \mu \mathrm{mol}$ and $1000 \mu \mathrm{mol})$ was prepared using the similar procedure. The results were expressed as $\mu \mathrm{mol}$ ascorbic acid /g extract sample.

\subsection{Free Radical Scavenging Activity}

1,1_-Diphenyl-_-picryl-hydrazyl radical scavenging (DPPH) Assay. The DPPH is a stable free radical and is widely used to assess the radical scavenging activity of antioxidant compounds. This method is based on the reduction of DPPH in methanol solution in the presence of a hydrogen-donating antioxidant due to the formation of the nonradical form DPPH-H (Blois, 1958). This transformation results in a color change from purple to yellow, which is measured spectrophotometrically. The disappearance of the purple color is monitored at $517 \mathrm{~nm}$. The free radical scavenging activity can be measured by using 2, 2-diphenyl-1-picryl-hydrazyl or 1, 1-diphenyl-2-picryl-hydrazyl by the method of McCune and Johns (2002). The reaction mixture (3.0 ml) consists of $1.0 \mathrm{ml}$ of DPPH in methanol $(0.3$ $\mathrm{mM}), 1.0 \mathrm{ml}$ of the extract and $1.0 \mathrm{ml}$ of methanol. It is incubated for $10 \mathrm{~min}$ in dark, and then the absorbance is measured at $517 \mathrm{~nm}$. In this assay, the positive controls can be ascorbic acid (Blois, 1958)

The percentage of inhibition can be calculated using the formula:

Inhibition $(\%)=(\mathbf{A 0}-\mathbf{A 1} / \mathbf{A 0}) \times 100$

Where; $\mathrm{A} 0$ is the absorbance of control and A1 is the absorbance of test.

\subsection{Reducing power (RP)}

The reducing power can be determined by JAYANTHI et al., 2011 method. Various concentrations of the plant extracts in corresponding solvents were mixed with phosphate buffer $(2.5 \mathrm{ml})$ and potassium ferricyanide $(2.5 \mathrm{ml})$. This mixture was kept at $50^{\circ} \mathrm{C}$ in water bath for 20 minutes. After cooling, $2.5 \mathrm{ml}$ of $10 \%$ trichloro acetic acid was added and centrifuged at $3000 \mathrm{rpm}$ for $10 \mathrm{~min}$ whenever necessary. The upper layer of solution $(2.5 \mathrm{ml})$ was mixed with distilled water $(2.5 \mathrm{ml})$ and a freshly prepared ferric chloride solution $(0.5 \mathrm{ml})$. The absorbance was measured at $700 \mathrm{~nm}$. Control was prepared in similar manner excluding samples. Ascorbic acid at various concentrations was used as standard. Increased absorbance of the reaction mixture indicates increase in reducing power. IC 50 is concentration of extract or standard to require absorbance is 0.50 .

\subsection{Statistical Analysis}

The significance of difference between means was determined by student's $t$ test where the values of $p<0.05$ were considered significant and those of $\mathrm{p}<0.01 \& \mathrm{P}<0.001$ were highly significant. Calculated value of $\mathrm{t}$ was determined by using software.

\section{RESUltS AND DisCUSSION}

\subsection{Proximate and Other Chemical Analyses}

The composition of developed ice cream is soy milk $65 \%$, sugar $27 \%$, oil $7 \%$, salt $0.2 \%$ and carboxy methyl cellulose $0.3 \%$. It was found that 100 grams of soy ice cream has $57.1 \pm 1.37 \%$ moisture, $6.98 \pm .04 \%$ fats, $5.47 \pm 0.45 \%$ protein, $29.33 \pm 1.46 \%$ carbohydrate, $0.011 \pm 0.001 \%$ fibre, $0.51 \pm 0.02 \%$ ash, $42.90 \pm 1.37 \%$ total solid and $27.40 \pm 0.61 \%$ sucrose. The energy is also calculated and $204 \pm 5.67 \mathrm{k}$ calorie was found per $100 \mathrm{gm}$ sample. On the other hand traditional market brand of ice cream contain $60.45 \pm 0.51 \%$ moisture, $13.02 \pm 0.68 \%$ fats, $2.26 \pm 0.06 \%$ protein, $23.68 \pm 0.61 \%$ carbohydrate, $0.009 \pm 0.001 \%$ fibre, $0.92 \pm 0.03 \%$ ash, $39.55 \pm 0.51 \%$ total solid and $20.37 \pm 1.29 \%$ sucrose (Table 1). Lactose is not present in soya ice cream but the content in traditional ice cream is $4.37 \pm 0.13 \%$ (Table 1 ).

Table1. Proximate and other chemical analysis (means $\pm S D, n=3$ )

\begin{tabular}{|l|l|l|}
\hline Test parameters & Soya ice cream & $\begin{array}{l}\text { Traditional ice cream (Market } \\
\text { brand) }\end{array}$ \\
\hline Moisture \% & $57.1 \pm 1.37$ & $60.45 \pm 0.51 \mathrm{NS}$ \\
\hline Ash\% & $0.50 \pm 0.02$ & $0.92 \pm 0.03^{*}$ \\
\hline protein\% & $5.47 \pm 0.45$ & $2.26 \pm 0.06^{*}$ \\
\hline Fat\% & $6.98 \pm 0.04$ & $13.02 \pm 0.68^{*}$ \\
\hline Crude fibre\% & $0.011 \pm .001$ & $0.009 \pm 0.001 \mathrm{NS}$ \\
\hline Carbohydrate \% & $29.93 \pm 1.46$ & $23.68 \pm 0.61^{*}$ \\
\hline
\end{tabular}


American Research Journal of Agriculture, Volume 1, Issue 1, February 2015

ISSN 2378-9018

\begin{tabular}{|l|l|l|}
\hline Sucrose \% & $27.40 \pm 0.61$ & $20.37 \pm 1.29^{*}$ \\
\hline Lactose \% & Absent & $4.37 \pm 0.13$ \\
\hline Total solid \% & $42.90 \pm 1.37$ & $39.55 \pm 0.51 \mathrm{NS}$ \\
\hline Calorie $(\mathrm{Kcal} / 100 \mathrm{gm})$ & $204.45 \pm 5.67$ & $220.94 \pm 3.89 \mathrm{NS}$ \\
\hline
\end{tabular}

Degree of freedom is 4 in all cases; $* P<0.01$ significant when compared to market brand traditional ice cream group versus soy ice cream group (Student's t- test).

NS = Non significant

Approximately $65-75 \%$ of people worldwide have decreased intestinal lactase levels, which may lead to lactose intolerance and difficulty digesting dairy products (Vesa et al., 2000 and Suarez et al., 1998). Lactose malabsorption occurs when lactose, the primary sugar in dairy products, is not completely digested and absorbed in the small bowel. Lactase, the enzyme required to hydrolyze lactose for intestinal absorption, is found primarily in tips of the villi in the jejunum (McCray, 2003).This soy product is lactose free and

\subsection{Mineral Analyses of Soy Ice Cream}

The mineral content of soybeans, determined as ash, is about five percent. When soybeans are processed, most of the mineral constituents go with the meal and few with the oil. The major mineral constituents are potassium, calcium and magnesium. The minor constituents comprise trace elements of nutritional importance, such as iron, zinc, copper etc.

Our soya ice cream contain remarkable amount of minerals and that are essential for our health. $100 \mathrm{gm}$ of soy ice cream contain $25.59 \pm 0.43 \mathrm{mg}$ calcium, $5.46 \pm 0.96 \mathrm{mg}$ iron, $11.16 \pm 0.48 \mathrm{mg}$ magnesium, $0.80 \pm 0.07 \mathrm{mg}$ zinc, 17.35 $\pm 0.70 \mathrm{mg}$ potassium, $86.43 \pm 0.71 \mathrm{mg}$ sodium $0.24 \pm 0.01 \mathrm{mg}$ manganese, and $0.56 \pm 0.03 \mathrm{mg}$ copper (Figure 1). Heavy metals such as arsenic, lead, chromium, stenus and cadmium are not present in developing product.

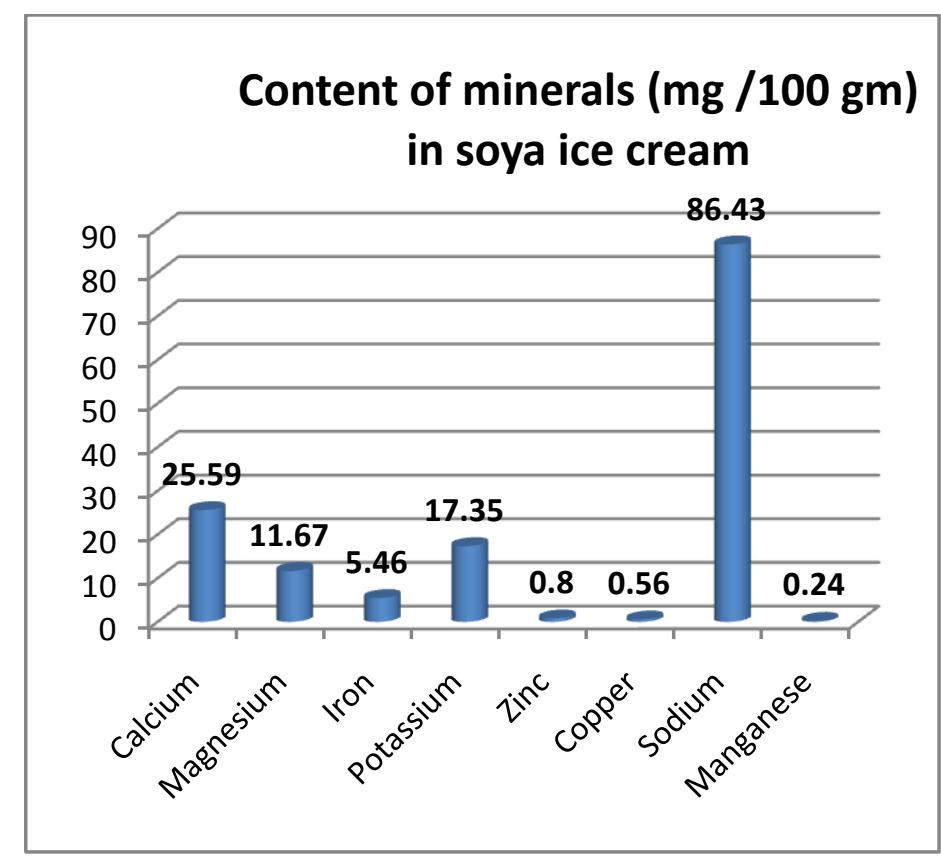

Figure1. Minerals content in soya ice cream per $100 \mathrm{gm}$.

\subsection{Sensory Evaluation}

The sensory evaluation showed that the product is very much acceptable (final comment from quality control section chief). Color, flavor and taste are like very much and texture and softness are like moderately.

\subsection{Phytochemicals Analyses}

The contents of phenolics, flavonoids and tannin are $23.69 \pm 0.45 \mathrm{mg}$ tannic acid equivalent, $14.57 \pm 0.45 \mathrm{mg}$ catechin equivalent and $3.81 \pm 027 \mathrm{mg}$ catechin equivalent in $100 \mathrm{gm}$ soya ice cream sample respectively (Table 2) but 
American Research Journal of Agriculture, Volume 1, Issue 1, February 2015

ISSN 2378-9018

traditional ice cream contain very much low amount of total phenolics that are significantly $(\mathrm{p}<0.001)$ lower than soya ice cream. But flavonoids and tannin were not present in traditional ice $\mathrm{c}$ ream that is collected from local market.

Table2. Content of phytochemicals in soy ice cream and traditional ice cream ( $\mathrm{mg} / 100 \mathrm{gm}$ fresh weight).

\begin{tabular}{|l|l|l|}
\hline Names of phytochemicals & Content (means \pm SD) in soy ice cream. & Content (means \pm SD) in traditional ice cream \\
\hline Total phenolics & $23.69 \pm 0.45$ & $5.74 \pm 0.47^{*}$ \\
\hline Flavonoids & $14.57 \pm 0.45$ & Absent \\
\hline Tannins & $3.81 \pm 0.27$ & Absent \\
\hline
\end{tabular}

Degree of freedom is 4 in all cases; $* P<0.001$ significant when compared to market brand traditional ice cream group versus soy ice cream group (Student's t- test). So Soy ice cream is better than traditional ice cream.

\subsection{Determination of Total Antioxidant Capacity}

The total antioxidant capacity in the methanolic extracts of soy ice cream was determined using the linear regression equation $(y=55.45 x+0.636, r 2=0.997$ and where $\mathrm{x}$ is absorbance and $\mathrm{y}$ is ascorbic acid concentration in microgram) of the calibration curve (Figure 3) and was expressed as ascorbic acid equivalent. The total antioxidant capacity of the soya ice cream is $505.61 \pm 9.770109 \mathrm{mg}$ Ascorbic acid equivalent/100g but the total antioxidant capacity of the traditional ice cream is $351.1033 \pm 4.211666 \mathrm{mg}$ Ascorbic acid equivalent/100g (Figure 2) and the capacity of soy ice cream is significantly $(\mathrm{p}<0.01)$ higher than traditional ice cream.

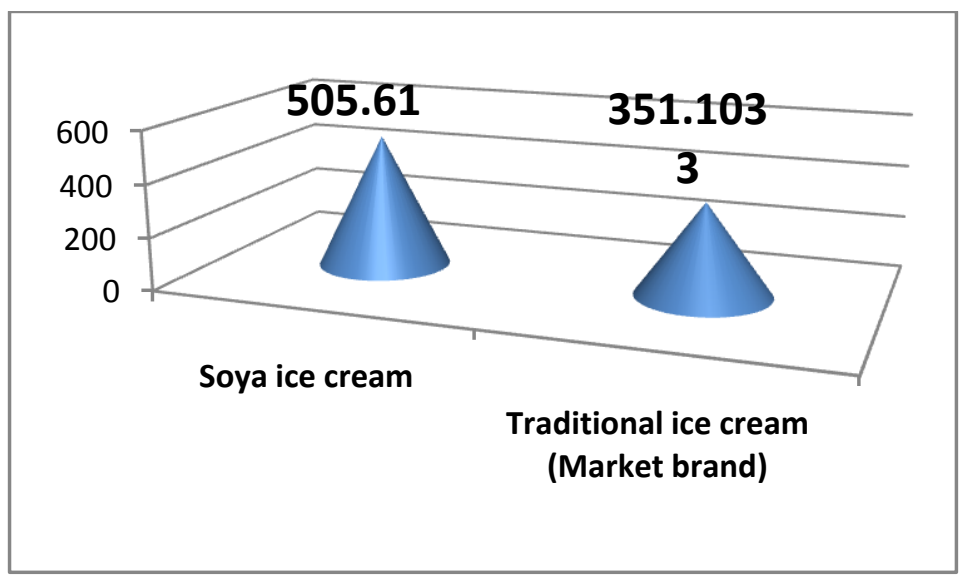

Figure2. Graphical presentation of total antioxidant content in soya ice cream and traditional ice cream.

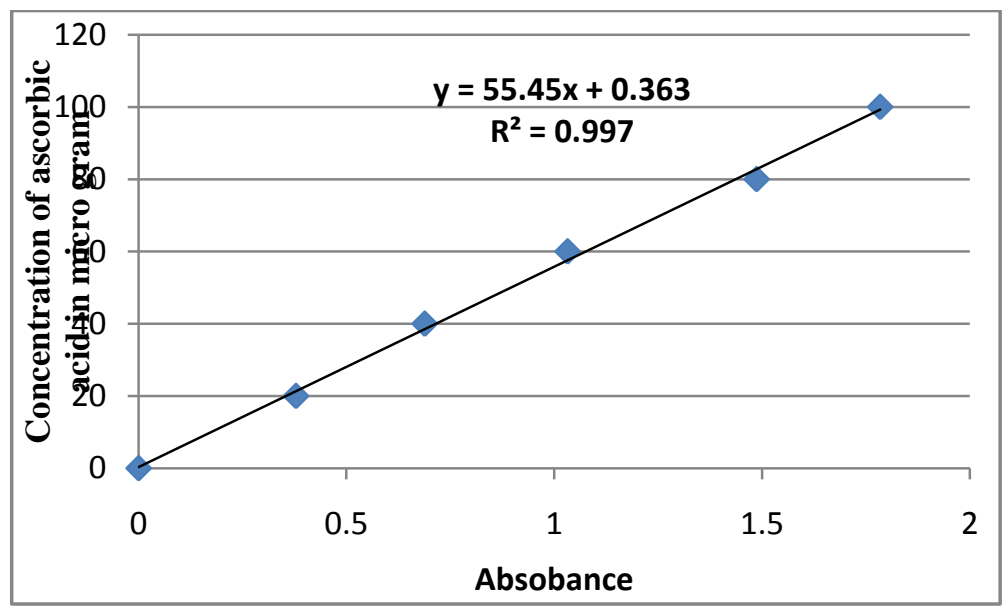

Figure3. Standard calibration curve of ascorbic acid for total antioxidant determination

\subsection{Determination of Ferric Reducing Antioxidant Power Assay (FRAP)}

In this study, the antioxidant activity is also determined on the basis of the ability of antioxidant in these ice cream extracts to reduce ferric (III) iron to ferrous (II) iron in FRAP reagent (Alothman et al., 2009; Wong et al., 2006). 
Generally, FRAP assay was used due to its simplicity and reproducibility. The standard curve of FRAP assay was shown in figure 4 . The antioxidant activity of ice cream extracts were $62.13 \pm 1.05 \mu \mathrm{mol}$ ascorbic acid/100 gm fresh soy ice cream and $33.67 \pm 2.08 \mu \mathrm{mol}$ ascorbic acid/100 gm traditional ice cream $(\mathrm{n}=3)$. Soy ice- cream has significantly higher antioxidant activity $(\mathrm{p}<0.01)$ than traditional ice cream. The ability to reduce $\mathrm{Fe}$ (III) may be attributed from hydrogen donation from phenolic compounds which is also related to presence of reductant agent. The higher absorbance of the reaction mixture indicated greater reducing power. The reducing properties are generally associated with the presence of different reductants. The antioxidant action of reductants is based on the breaking of the free radical chain by donating a hydrogen atom. Reductones also react with certain precursors of peroxide, thus preventing peroxide formation. The reductive power of different fractions of long bean extract and gallic acid may be the reason for their antioxidant activity (Emynur Shafekh et al., 2012).

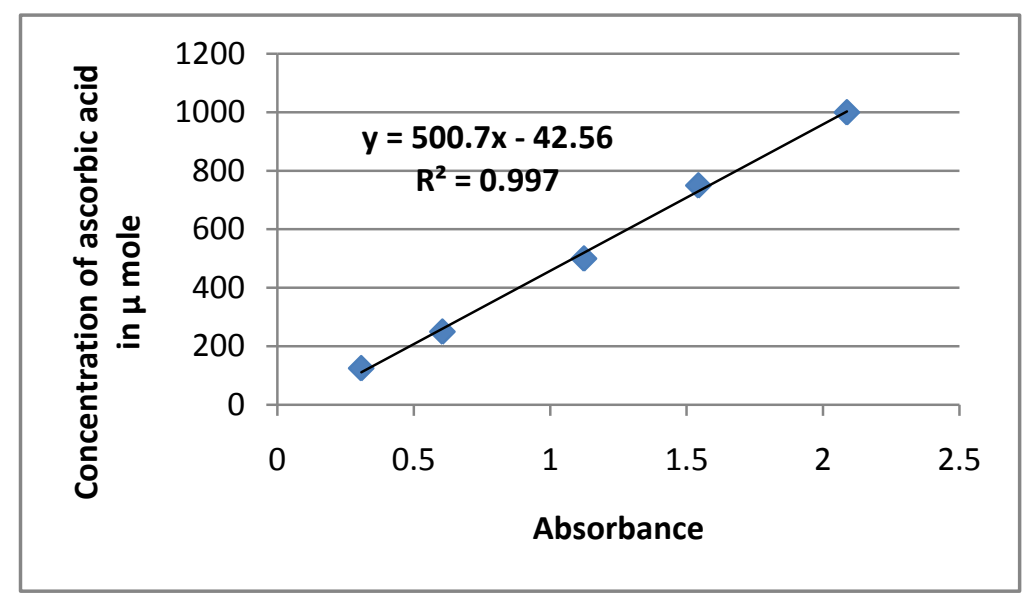

Figure4. Standard curve of FRAP assay

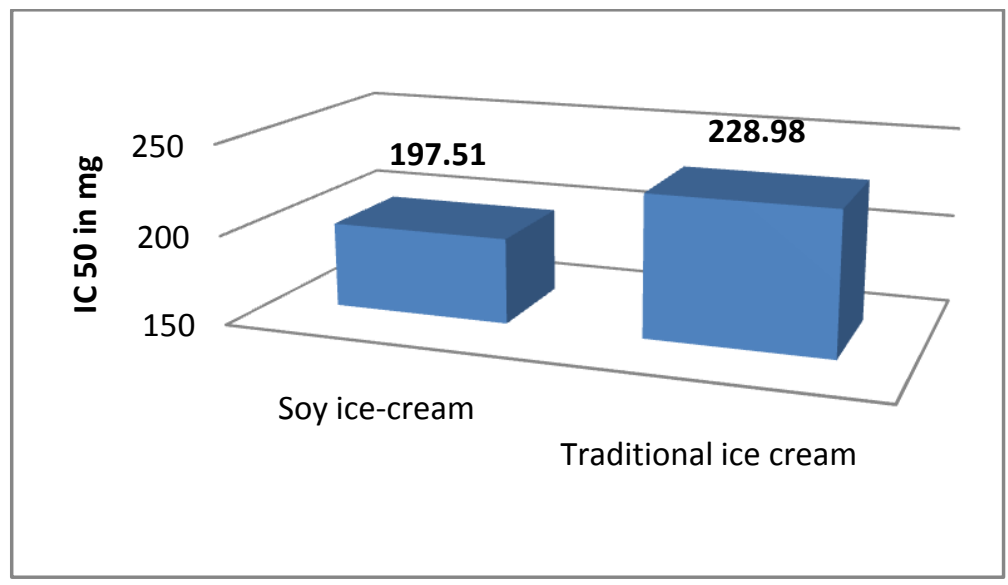

Figure5. Comparative reducing power of soy ice cream and traditional ice cream

\subsection{DPPH Free Radical Scavenging Assay}

The IC 50 value soya ice cream in DPPH free radical scavenging method is $156.24 \mathrm{mg} / \mathrm{ml}$ (Table 4) and standard ascorbic acid is 5.69 microgram $/ \mathrm{ml}$ (Table 3) but traditional ice cream has no DPPH free radical scavenging activity. Radical scavenging activities are very important due to the deleterious role of free radicals in foods and in biological systems. Chemical assays are based on the ability to scavenge synthetic free radicals, using a variety of radicalgenerating systems and methods for detection of the oxidation end-point. DPPH radical scavenging methods are common spectrophotometric procedure for determining the antioxidant capacities of component.

DPPH has been widely used to evaluate the free radical scavenging effectiveness of various antioxidant substances (O" zcelik et al., 2003). In the DPPH assay, the antioxidants were able to reduce the stable radical DPPH to the yellow coloured diphenyl-picrylhydrazine. The method is based on the reduction of alcoholic DPPH solution in the presence of a hydrogen-donating antioxidant due to the formation of the non-radical form DPPH-H by the reaction. DPPH is usually used as a reagent to evaluate free radical scavenging activity of antioxidants (Oyaizu, 1986). DPPH 
is a stable free radical and accepts an electron or hydrogen radical to become a stable diamagnetic molecule (Soares et al., 1997).

With this method it was possible to determine the antiradical power of an antioxidant by measuring of a decrease in the absorbance of $\mathrm{DPPH}_{\text {_ }}$ at $517 \mathrm{~nm}$. Resulting a color change from purple to yellow, the absorbance decreased when the DPPH_ was scavenged by an antioxidant through donation of hydrogen to form a stable DPPH_molecule. In the radical form, this molecule had an absorbance at $517 \mathrm{~nm}$ which disappeared after acceptance of an electron or hydrogen radical from an antioxidant compound to become a stable diamagnetic molecule.

A simple method utilizing the stable 2,2-diphenyl- 1-picrylhydrazyl (DPPH) radical has been developed to determine the antioxidant activity of natural products. The odd electron in the DPPH free radical gives a strong absorption maximum at $517 \mathrm{~nm}$ and is purple in color. The color turns from purple to yellow as the molar absorptivity of the DPPH radical at $517 \mathrm{~nm}$.

Table3. \% of inhibition of DPPH free radical scavenging activity and IC 50 of ascorbic acid

\begin{tabular}{|c|c|c|c|}
\hline Concentration in $\mu \mathrm{g}$ & \% of Inhibition & $\begin{array}{l}\text { Linear regression equation [ ascorbic acid } \\
\text { concentration }(\mu \mathrm{g}) \text { vs. \% of inhibition] }\end{array}$ & IC 50 in $\mu \mathrm{g} / \mathrm{ml}$ \\
\hline 5 & $66.99 \pm 2.13$ & \multirow{5}{*}{$Y=3.368 x+30.85$} & \multirow{5}{*}{5.69} \\
\hline 10 & $83.52 \pm 1.29$ & & \\
\hline 15 & $91.83 \pm 0.88$ & & \\
\hline 20 & $97.50 \pm 0.73$ & & \\
\hline 25 & $97.92 \pm 0.44$ & & \\
\hline
\end{tabular}

Table4. \% of inhibition of DPPH free radical scavenging activity and IC 50 of soya ice cream

\begin{tabular}{|c|c|c|c|}
\hline Concentration in $\mathrm{mg}$ & \% of Inhibition & $\begin{array}{l}\text { Linear regression equation [ ice cream } \\
\text { concentration }(\mathrm{mg}) \text { vs. \% of inhibition] }\end{array}$ & IC 50 in $\mathrm{mg} / \mathrm{ml}$ \\
\hline 9.34 & $4.44 \pm 0.09$ & \multirow{5}{*}{$Y=0.314 x+0.942$} & \multirow{5}{*}{156.24} \\
\hline 18.68 & $7.95 \pm 0.17$ & & \\
\hline 28.01 & $9.76 \pm 0.51$ & & \\
\hline 37.35 & $11.75 \pm 0.11$ & & \\
\hline 46.69 & $15.81 \pm 0.13$ & & \\
\hline
\end{tabular}

\subsection{Reducing power (RP)}

The reducing power of methanolic extracts of ice-cream was found to be correlated with increasing absorbance (at $700 \mathrm{~nm})$ as compared with ascorbic acid, a known antioxidant. The $\mathrm{IC}_{50}$ of ascorbic acid is $31.12 \pm 0.13(\mathrm{n}=3)$ micro gram and the IC ${ }_{50}$ of soya ice cream and traditional ice - cream were $197.51 \pm 0.83$ and $228.98 \pm 1.74 \mathrm{mg}$ (fresh weight) respectively. IC ${ }_{50}$ of soya ice cream is significantly ( $\left.\mathrm{p}<0.01\right)$ lower than traditional ice cream. Lower IC ${ }_{50}$ indicates the higher antioxidant activity. So soya ice cream has better reducing power than traditional market brand ice cream. Polyphenols in the soy ice-cream extracts appear to function as good electron and hydrogen atom donors and therefore should be capable of converting free radicals to more stable products. Reducing power is associated with antioxidant activity and may serve as a significant reflection of the antioxidant activity (Oktay et al., 2003). Soy ice-cream with reducing power indicate that they are electron donors and can reduce the oxidized intermediates of lipid peroxidation processes, so that they can act as primary and secondary antioxidants (Yen and Chen, 1995).

Only soy milk was used in this soy product and soy milk contains good amounts of protein, polysaccharides and indigestible fibre, unsaturated fat and lecithin, vitamins and minerals, as well as bioactive organic molecules including polyphenols, such as phenolic acids, isoflavones, tannins and saponins (Anderson, 2000). The contents of phenolics, flavonoids and tannin are $23.69 \pm 0.45 \mathrm{mg}$ tannic acid equivalent, $14.57 \pm 0.45 \mathrm{mg}$ catechin equivalent and $3.81 \pm 027 \mathrm{mg}$ catechin equivalent in $100 \mathrm{gm}$ soy ice cream respectively (Table 2 ). These phytochemicals may added from soyabean during the development of soya ice cream because soya bean contain secondary metabolites, such as, isoflavones, phyto-sterols, lecithins, saponins and many more (Ajay , 2011). Polyphenolic compounds have an important role in stabilizing lipid oxidation and areassociated with antioxidant activity (Cook, and Samman, 1996). Antioxidative properties of polyphenols arise from their high reactivity as hydrogen or electron donors from the ability of the polyphenol derived radical to stabilize and delocalize the unpaired electron (chain-breaking function) and from their potential to chelate metal ions (termination of the Fenton reaction) (Rice-Evans et al., 1997). Phenolics acid possesses diverse biological activities, for instance, antiulcer, anti- inflammatory, antioxidant (Silva, 2007), cytotoxic and antitumor, antispasmodic, and antidepressant activities (Ghasemzadeh, 2010). We hope that this soya product may possess the above biological activities in human body when taking. 
This product is a good source of flavonoid (Table 2) and flavonoids present in food of plant origin are also potential antioxidants (Satheeshkumar, 2011). The antioxidative properties of flavonoids are due to several different mechanisms, such as scavenging of free radicals, chelation of metal ions, such as iron and copper, and inhibition of enzymes responsible for freeradical generation (Benavente-Garcia, 1997). Depending on their structure, flavonoids are able to scavenge practically all known ROS. The many pharmacological effects of phenolic compounds and flavonoids are linked to their ability to act as strong antioxidants and free radical scavengers, to chelate metals, and to interactwith enzymes, adenosine receptors, and biomembranes. It was reported that the antioxidant activity of plant materials was well correlated with the content of their phenolic compounds (Sathyaprabha, 2011).

Tannin is also found in this product and they show also antioxidant activity ().Several health benefits have been recognized for the intake of tannins and some epidemiological associations with the decreased frequency of chronic diseases have been established (Serrano, 2009).

\section{CONCLuSion}

Lactose free and antioxidant based this non dairy soy ice cream provide a wide range of nutrients to lead a healthy and active life of human. Components of the diet must be chosen judiciously to provide all the nutrients to meet the human requirements in proper proportions for the different physiological activities. Now large amount of soybean is cultivated in rural area of Bangladesh .Soybean is one of the good sources of high quality oil and protein can play an important role in solving the malnutrition problem of Bangladesh. Low income people can easily fill up their protein demand by consuming this soya product because cost of this product is will be lower than traditional ice cream in local market. As per we know soya ice cream industry is not present in Bangladesh. So this project may help the industrialist to develop this new soya product by using local soybean. We concluded that lactose free, low fat and low carbohydrate containing this soya product may provide the protein, minerals, phytochemicals and antioxidant for the different physiological activities of human body.

\section{ACKNOWLEDGEMENTS}

The authors are grateful to the BCSIR authority for providing project: "Development of various types of proteinenrich food (soya drinks, snacks etc) from legumes as major protein source" and providing fund during the project running time. The authors are also grateful to Dr. Tasnim Farzana, section in- charge and senior scientific officer, Quality control research section, IFST, BCSIR for completing and giving report of sensory evaluation of this product.

\section{REFERENCES}

[1] Abdelseed, B.H., Abdalla, A.H., Yagoub, A.E.A., Mohamed Ahmed, I.A. and Babiker, E.E. 2011. Some Nutritional Attributes of Selected Newly Developed Lines of Sorghum (Sorghum bicolor) after Fermentation. Journal of. Agricultural Science and Technology 13: 399-409.

[2] Alothman, M., Bhat, R. and Karim, A.A. 2009. Antioxidant capacity and phenolic content of selected tropical fruits from Malaysia, extracted with different solvents. Food Chemistry 115: 785-788.

[3] Anderson, J.J.B. and Garner, S.C. 2000. The soybean as a source of bioactive molecules. In: Schmidl, M.K. and Labuza, T.P. (eds.) Essentials of functional foods. Aspen Publishers. Gaithersburg, MD, USA. pp. 239-269.

[4] AOAC. 2006. Methods of Analysis: 18th Ed. Washington, DC: Association of Official Analytical Chemists.

[5] Ajay, K. D., Antony, J. I. X., Navin K. S. and Rakesh K. T. 2011. Soybean constituents and their functional benefits. Opportunity, Challenge and Scope of Natural Products in Medicinal Chemistry 367-383.

[6] Benavente-Garcia, O., Castillo, J., Marin, F.R., Ortuño, A. and Del-Rio, J. A. 1997. Uses and properties of Citrus flavonoids. Journal of Agricultural and Food Chemistry 45: 4505-4515.

[7] Blois, M.S. 1958. Antioxidant determinations by the use of a stable free radical. Nature 181: 1199-1150.

[8] Chang, C., Yang, M., Wen, H. and Chern, J. J. 2002. Estimation of total flavonoid content in) propolis by two complementary colorimetric methods. Journal of Food Drug Analysis 10:178- 182.

[9] Chinma, C. E. and Igyor, M. A. 2007. Micronutrients and anti-nutritional contents of Selected tropical vegetable grown in South East Nigeria. Nigerian Food Journal 25: 111-116.

[10] Cook, N.C., and Samman, S. 1996. Flavonoids Chemistry. Metabolism,Cardioprotective effects and dietary sources . Journal of Nutritional Biochemistry 7:66-76.

[11] Emynu, S., S., Mohd, A. K. R., Catherine, C.C.W., Siti, S.Z.A., Ummu, H.A., Norhayati, $\quad$ A.H., Nor, F.M.Y., Noor , H,Z., Siti, N.M.B., Azlina, M., Noor, S. S. A.R. and Ahmad, Z.A.L. 2012. Total phenolic content and in vitro antioxidant activity of Vigna sinensis, International Food Research Journal 19: 1393-1400. 
[12] Eneche, E. H. 1991. Biscuit-making potential of millet/ pigeon pea flour blends. Plant Foods Human Nutrition 54: $21-27$.

[13] Ghasemzadeh, A., Jaafar, H.Z.E. and Rahmat, A. 2010. Antioxidant activities, total Phenolics and flavonoids content in two varieties of Malaysia Young Ginger ( Zingiber officinale Roscoe). Molecules 15: 4324-4333.

[14] Isong, N. B., Akpan, M. M. and Udofia, N. A. 2013. Nutritional composition, sensory evaluation and microbial activities of the traditional and enriched 'Akara Iwe' from Uya Oron in Akwa Ibom State, Nigeria West Africa. European Journal of Experimental Biology 3:519-525

[15] Jayanthi, P. and Lalitha, P..2011.Reducing power of the solvent extracts of Eichhornia crassipes (Mart.) solms. International Journal of Pharmacy and Pharmaceutical Sciences, $3: 126$.

[16] Kirk, R. S. and Sawyer, R. 1991. Pearson's composition and analysis of foods (9th ed.). London: Addison-Wesley Longman, Inc. Chapter $2 \& 14$.

[17] Maizura, M., Aminah, A. and Wan Aida, W. M. 2011,Total phenolic content and antioxidant activity of kesum (Polygonum minus), ginger (Zingiber officinale) and turmeric (Curcuma longa) extract. International Food Research Journal 18: 529534.

[18] McCune, L. M. and Johns, T. 2002. Antioxidant activity in medicinal plants associated with the symptoms of diabetes mellitus used by the indigenous peoples of the North American boreal forest. J. Ethnopharmacol 82: 197-205.

[19] McDonald, S., Prenzler, P.D., Antolovich, M. and Robards, K. 2001. Phenolic content and antioxidant activity of olive extracts. Food Chemistry 73: 73-84.

[20] Messina, M. and Lane, B. 2007. Soy protein, soybean isoflavones and coronary heart disease risk: where do we stand? Future Lipidology 2, 55-74.

[21] Murphy, P. A., Song, T., Buseman, G., Barua, k., Beecher, G. R., Trainer, D. and Holden, J. 1999. Isoflavones in retail and institutional soy foods. J. Agricultural and Food Chemistry 47: 2697-2704.

[22] Nwabueze, T.U. 2007. Nitrogen solubility index and amino acid profile of extruded African breadfruit (T.africana) blends. Nigerian Food Journal 25: 23-35.

[23] Oktay, M., Gulcin, I. and Kufrevioglu, O. 2003. Determination of in vitro antioxidant activity of fennel (Foeniculum vulgare) seed extracts. Lebensmittel-Wissenschaft \& Technologie 36: 263-271

[24] Oyaizu, M., 1986. Studies on product of browning reaction prepared from glucose amine. Japanese Journal of Nutrition 44: 307.

[25] O“zcelik, B., Lee, J.H. and Min, D.B. 2003. Effects of light, oxygen and pH on the 2,2-diphenyl-1-picrylhydrazyl (DPPH) method to evaluate antioxidants. Journal of Food Sciences 68: 487.

[26] Rice-Evans, C. 2004. Flavonoids and isoflavones: absorption, metabolism and bioactivity. Free Radical Biology and Medicine 36: 827-828.

[27] Satheeshkumar, D., Kottai, A. M. and Manavalan, R. 2011. Antioxidant potential of various extracts from whole plant of Ionidium suffruticosum (Ging), Research Journal of Pharmaceutical, Biological and Chemical Sciences $2: 286$.

[28] Sathyaprabhaa, G., Kumaravelb, S. and Panneerselvam A. 2011. Analysis of Antioxidant activity, Total Phenol, Total Flavonoid and screening of Phytocomponents in Pleurotus platypus and Pleurotus eous, Journal of Chemical and Pharmaceutical Research 3:1-6.

[29] Serrano, J., Puupponen-Pimia, R., Dauer, A., Aura, A. and Saura-Calixto, F. 2009. Tannins: current knowledge of food sources, intake, bioavailability and biological effects. Molecular Nutrition Food Research 53: 310-29.

[30] Silva, E.M., Souza, J.N.S., Rogez, H., Rees, J.F. and Larondelle, Y. 2007. Antioxidant activities and polyphenolic contents of fifteen selected plant species from the Amazonian region. Food Chemistry 101: 1012-18.

[31] Soares, J.R., Dins, T.C.P., Cunha, A.P. and Almeida, L.M. 1997. Antioxidant activity of some extracts of Thymus zygis. Free Radical Research 26:469.

[32] Takahashi, R., Ohmori, R., Kiyose, C., Momiyama, Y., Ohsuzu, F. and Kondo, K. 2005. Antioxidant Activities of Black and Yellow Soybeans Against Low Density Lipoprotein Oxidation. Journal of Agricultural and Food Chemistry 53 :4578-4582

[33] Wiwat, W. 2012. Development of ginger-flavoured soya milk ice cream: Comparison of data analysis methods. Maejo International Journal of Science and Technology $6: 505-513$.

[34] Wiwat, W. 2008. Nutrition data and antioxidant capacity of soy milk ice cream and black sesame flavoured soy milk ice cream. As. J. Food Ag-Ind 1: 205-212.

[35] Wong, C., Li, H., Cheng, K. and Chen, F. 2006. A systematic survey of antioxidant activity of 30 Chinese medicinal plants using the ferric reducing antioxidant power assay. Food Chemistry 97: 705-711.

[36] Yang, C.S., Landau, J.M., Huang, M.T. and Newmark, H.L. 2001. Inhibition of Carcinogenesis by Dietary Polyphenolic Compounds. Annual Review Nutrition 21: 381-406.

[37] Yen, G.C. and Chen, H.Y. 1995. Antioxidant activity of various tea extracts in relation to their antimutagenicity. Journal of Agricultural and Food Chemistry 43: 27-32 